Journal of Environmental Sciences (JES)

Faculty of Graduate Studies and Environmental Research, Ain Shams University

Abdel-Rahman., et al.

\title{
REPLACEMENT CORN SILAGE BY DUCKWEED SILAGE IN BARKI LAMBS RATIONS
}

\author{
Maged G. Abdel-Rahman ${ }^{(1)}$; Foad A. Salem ${ }^{(2)}$; \\ Ahmed M. Elsherbiny ${ }^{(2)}$; Hamdy M. Metwally ${ }^{(2)}$; Tark A. Deraz ${ }^{(3)}$ \\ and Haasan S. Abbas ${ }^{(3)}$
}

1) Post Grad Student, Faculty of Graduate Studies and Environmental Research, Ain Shams University 2) Department of Animal Production, Faculty of Agriculture, Ain-Shams University, Egypt 3) Animal Production Research Institute, Agricultural Research Center, Dokki, Giza, Egypt.

\begin{abstract}
The present work was conducted to study the effect of replacement corn silage (CS) by duckweed silage (DS) improved the performance of growing Barki lambs using one of the following rations: R1: $2 \%$ of body weights (BW) concentrate feed mixture (CFM) + CS (control), R2: $1.5 \%$ of BW $(\mathrm{CFM}+\mathrm{DS}), \mathrm{R} 3: 1.75 \%$ of BW( CFM + DS) and R4: $2 \%$ of BW (CFM + DS). Results showed the silages had good smell and were free from any signs of molds in all groups. Digestibility trial was conducted using twelve mature local Barki breed were divided four groups (3 animals each) and were determined digestibility coefficients. Animals in group R3 recorded $(\mathrm{P}<0.05)$ the highest digestibility coefficients for all nutrients and nutritive value than others. These results showed a significant improvement $(\mathrm{P}<0.05)$ in digestibility coefficients of NDF, ADF and cellulose in R3 than other groups. Results showed insignificant differences $(\mathrm{P}>0.05)$ among the three tested groups treatment in all blood parameters. The second experimental trials were twenty Barki lambs with average body weight of $20.00 \pm 2.0 \mathrm{~kg}$ /head were used. Lambs were divided into four groups (5 animals each) and fed the four respective rations with the same regime of feeding the experimental lasted for month. R3 recorded the highest value of average
\end{abstract}


daily gain compared with $\mathrm{R} 4, \mathrm{R} 1$ and $\mathrm{R} 2$. Also, $\mathrm{R} 3$ recorded the best value of feed conversion (g DM/g gain) were (4.43) followed by the R2 (4.76), followed by R1 (5.51) than R4(5.65). It was concluded that replacing corn silage by duckweed silage to rations of growing Barki lambs could improve their performance, digestibility, average daily gain and feed conversion. However, for improved performance of the lambs and economic benefits (R3) is recommended.

Keywords: Corn silage, Duckweed silage, digestibility, blood parameters, Barki lambs.

\section{INTRODUCTION}

In Egypt as in other developing countries, there is a serious problem of feed shortage especially protein sources. (Badawy, 2014) noticed that provision of the quality of protein in lamb's diet does not only improve animal performance but also ensures profitable animal production. Sheep is a multi-functional animal and plays a significant role in the economy and nutrition of landless, small and marginal farmers in the country. Sheep rearing is an enterprise which has been practiced by a large section of population in rural areas. Sheep can efficiently survive on available shrubs and trees in adverse harsh environment in low fertility lands where no other crop can be grown. Duckweeds have great application in genetic or biochemical research. This has been more or less in the same way that drosophila (fruit flies) and bread mold have been used as inexpensive medium for genetic, morphological and physiological and biochemical research (Alica et al., 2015).

640 
Journal of Environmental Sciences (JES)

Faculty of Graduate Studies and Environmental Research, Ain Shams University

Abdel-Rahman., et al.

The aim of this study the effect of using duckweed silage on their nutrients digestibility, feeding value, rumen fermentation, lamb performance and their feed economic efficiency.

\section{MATERIALS AND METHODS}

This study was carried out at the Noubaria Experimental Station, ByProducts Utilization Research Department, Animal Production Research Institute, Agricultural Research Center, Ministry of Agriculture and Land Reclamation. Investigate the effect of feeding duckweed silage on the performance of Barki lambs. The experimental work of this study was carried out at the By-Products Utilization Research Department, Animal Production Research Institute, Agricultural Research Center, Ministry of Agriculture and Land Reclamation. Three feed ingredients (duckweed (DW), rice straw (RS) and molasses) laboratory trial. Three treatments were made from laboratory duckweed silage and put in jars (10 jars for each) about 35 days. The first: $550 \mathrm{~g} \mathrm{DW}+400 \mathrm{~g} \mathrm{RS}+50 \mathrm{~g}$ molasses. The second: $600 \mathrm{~g} \mathrm{DW}+350 \mathrm{~g}$ RS + 50g molasses. The third: 650g DW + 300g RS + 50g molasses. The best results were for the smell second treatments were in $\mathrm{pH}$, smell and color of silage. A total of $400 \mathrm{~kg}$ was collected for duckweed a canal farms youth graduates Noubaria and four basin were established for growing duckweed and it development with agriculture water each basin space (10 meters long and 3 meters wide) put $100 \mathrm{~kg}$ duckweed on four 
Journal of Environmental Sciences (JES)

Faculty of Graduate Studies and Environmental Research, Ain Shams University

Abdel-Rahman., et al.

basin and added superphosphate and organic fertilizers. Duckweed was weighed after 10 days follows: The first basin: $185 \mathrm{~kg}$. The second basin: $182 \mathrm{~kg}$. The third basin: $179 \mathrm{~kg}$ and The fourth basin: $182 \mathrm{~kg}$. Total amount for all $(4$ basin $)=728$.

\section{Total amount increased of weight for duckweed after $\mathbf{1 0}$ days were:}

$728-400=328 \mathrm{~kg}$

$\%$ of increased $=328 \backslash 400=82 \%$

The biomass was mixed well $(60 \%$ duckweed $+35 \%$ RS $+5 \%$ molasses) total account of all ingredients (700 kg duckweed $+410 \mathrm{~kg} \mathrm{RS}+$ $60 \mathrm{~kg}$ molasses) after 45 days were opened for feeding and sampled for chemical analysis. Silage $\mathrm{pH}$ was directly determined using Orian 680 digital $\mathrm{pH}$ meter, while TVFA's and ammonia nitrogen concentrations were determined according to the method that recorded by Warner (1964) and Bergen et al. (1974). Molasses was added of the mixed material. Molasses was diluted by certain volume of water capable to increase the moisture content of the ensiled mixture to about 65 percent. The silos bottom was covered by thin layer of rice straw to absorb the seepage. The ensiled mixture was one ton for T2 treatment. The silage heaps were sealed with plastic sheet and pressed well by a tractor and compacted with $20-\mathrm{cm}$ layer of clay. The proximate analysis of the raw materials used in preparing the experiment is presented as follow: (Table 1). Silage $\mathrm{pH}$ was directly determined using Orian 680 digital pH meter, while TVFA's and ammonia 642 
nitrogen concentrations were determined according to the method that recorded by Warner (1964) and Bergen et al. (1974).

Table (1): Chemical composition (\% on DM basis) of corn silage (CS), duckweed (D), duckweed silage (DS), rice straw (RS) and concentrate feed mixture $(\mathrm{CFM})^{*}$.

\begin{tabular}{|c|c|c|c|c|c||}
\hline Item & CS & D & DS & RS & CFM* $^{*}$ \\
\hline \hline DM & 31.96 & 7.36 & 32.55 & 91.21 & 88.70 \\
\hline OM & 81.91 & 78.15 & 82.80 & 84.38 & 91.20 \\
\hline CP & 7.44 & 24.61 & 6.94 & 3.63 & 15.70 \\
\hline CF & 27.59 & 15.05 & 27.96 & 37.54 & 12.90 \\
\hline EE & 3.60 & 3.59 & 2.34 & 0.99 & 3.20 \\
\hline NFE & 43.28 & 34.90 & 45.56 & 42.22 & 59.40 \\
\hline Ash & 18.09 & 21.85 & 17.20 & 15.62 & 8.80 \\
\hline NDF & 35.62 & 81.65 & 33.96 & 74.2 & 27.79 \\
\hline ADF & 26.14 & 67.72 & 23.81 & 40.31 & 8.86 \\
\hline ADL & 5.02 & 37.84 & 4.77 & 8.50 & 2.89 \\
\hline Cellulose & 21.21 & 29.88 & 19.04 & 31.81 & 5.88 \\
\hline Hemicelluloses & 9.48 & 13.93 & 10.15 & 33.89 & 18.89 \\
\hline
\end{tabular}

* Concentrate feed mixture (CFM) consisted of: 38\% ground yellow corn, $22 \%$ undecorticated cotton seed meal, $7 \%$ soybean meal, $12 \%$ wheat bran, $13 \%$ rice bran, $5 \%$ cane molasses, $2 \%$ lime stone and $1 \%$ common salt.

The official methods of the A.O.A.C (2000) were used to determine DM, OM, CP, CF, EE and ash percentages. Nitrogen free extract (NFE) was calculated by difference. They were assigned at random to the four experimental rations: R1: $2 \%$ of body weights concentrate feed mixture $(\mathrm{CFM})+$ corn silage (control). R2: $1.5 \%$ of body weights CFM + duckweed silage. R3: $1.75 \%$ of body weights CFM + duckweed silage and R4: $2 \%$ of 
body weights CFM + duckweed silage (Table 2). The CP value obtained in the present study was found to be similar to values reported by Renu et al., (2018) and Sonam et al., (2020).

Table (2): Chemical composition (\% on DM basis) of experimental rations.

\begin{tabular}{|c|c|c|c|c|}
\hline \multirow{2}{*}{ Item } & \multicolumn{4}{|c|}{ Experimental rations } \\
\cline { 2 - 5 } & R1 & $\mathbf{R 2}$ & $\mathbf{R 3}$ & R4 \\
\hline \hline DM & 73.90 & 73.60 & 72.52 & 76.14 \\
\hline OM & 88.78 & 88.94 & 88.78 & 89.32 \\
\hline CP & 13.55 & 13.34 & 13.18 & 13.74 \\
\hline CF & 16.73 & 16.95 & 17.24 & 16.27 \\
\hline EE & 3.30 & 2.97 & 2.95 & 3.01 \\
\hline NFE & 55.20 & 55.78 & 55.41 & 56.30 \\
\hline Ash & 11.22 & 11.06 & 11.22 & 10.68 \\
\hline
\end{tabular}

Animals were fed according to NRC (1985) recommendations. Twenty Barki lambs an average live body weight $20.00 \pm 2.0 \mathrm{~kg}$ were assigned to three groups according to live body weight (5 lambs for each). They were assigned at random to the four experimental rations. The animals were fed the four respective rations in two meals/day ( 8 a.m. and 3 p.m.) and housed individually in a 120 day feeding trial. The lambs were weighed biweekly in the morning before feeding, through four months. At the end of the experimental feeding, nutrients digestibility coefficients were estimated using three rams for each ration. The fecal samples were collected twice daily during 7 days from all groups. Feces samples of each ram were mixed well and kept in the refrigerator for chemical analysis, samples of feed and feces were analyzed according to A.O.A.C. (2000). Rumen liquor samples 644

Vol.(50); Iss.(10); No.(7); Oct.. 2021

ISSN $1110-0826$

Online ISSN 2636-3178 
were taken for two successive days from all animals. The sampling times were 0 (before feeding), 3 and 6 hours after feeding. Ruminal $\mathrm{pH}$ and ammonia $\mathrm{NH}_{3}-\mathrm{N}$ were determined immediately after collection. Samples of rumen liquor for TVFA's determinations were frozen until the analysis time. Sampling of rumen fluid were collected by using stomach tube and filtered through two layers of cheese cloth before being used to determine the following parameters: The ruminal $\mathrm{pH}$ values were measured immediately by pH meter (Orion Research, model 201/digital pH meter).Ammonia nitrogen $\left(\mathrm{NH}_{3}-\mathrm{N}\right)$ was determined and TVFA's concentration was determined by the steam distillation method according to Abou-Akkada and Osman (1967). Blood samples were drawn from the jugular vein from three lambs of each group at 4 hours after morning feeding and centrifuged for 20 min at 3000 r.p.m. The supernatant was frozen and stored at $-20 \mathrm{oC}$ for subsequent analysis. Serum blood total protein was determined according to (Armstrong and Carr 1964); albumin according to (Doumas et al., 1971); ALT and AST according to (Reitman and Frankel, 1957); and urea according to (Siest et al., 1981). Collected data of nutrients digestibilities, rumen fermentation, blood parameters and growth performance were subjected to statistical analysis using one-way-analysis of variance uses the following mathematical model:

$$
Y \mathbf{i j}=\mu+\mathbf{T i}+\mathbf{e i j}
$$


Where: Yij is the parameter under analysis, $\mu$ is the overall mean, Ti is the effect due to treatment and eij is the experimental error. The general linear model of SAS (2001) program was used in processing measured parameters. The difference between means was statistically measured for significance at $(\mathrm{P}<0.05)$ according to Duncan (1955).

\section{RESULTS AND DUSCUSSION}

Silage characteristics: Fermentation characteristics of all silages during the ensiling period indicated a successful processing (Table, 3). In all the treatments, the silage was ready to use after 45 days. Silages had good better smell and were free from any signs of molds. Values of $\mathrm{pH}$ indicated good preserved silage as it decreased with advancing ensilaging period where it reached 6.98 to 4.15 from 0 to 45 days for T1. But, T2 $\mathrm{pH}$ value were 6.70 to 4.05 from 0 to 45 days and $\mathrm{T} 3 \mathrm{pH}$ values were 6.55 to 3.88 from 0 to 45 days, respectively. Optimal growth occurs around neutral $\mathrm{pH}$ for duckweed (Leng, 1999) and at around $\mathrm{pH}$ 6. The lower limit of $\mathrm{pH}$ for growth in most species is disputed with Landolt (1986). A main quality criteria of silage is $\mathrm{pH}$, and based on $\mathrm{pH}$, silage is generally classified as very good ( $\mathrm{pH} 3.8$ to 4.2$)$, good $(\mathrm{pH} 4.2$ to 4.5$)$, and fair silage $(\mathrm{pH}>4.5)$ (Thomas, 2008). 
Also, low values for $\mathrm{NH}_{3}-\mathrm{N}$ concentration $(2.50 \mathrm{~g} \backslash \mathrm{kg} \mathrm{DM})$ was $\mathrm{T} 1$ from 0 days but the high value was (2.95 $\mathrm{glkg} \mathrm{DM}$ ) from T3 (35 days). These results are matched with those recorded by Landolt (1986) and Indulekha et al., (2019). The changes in $\mathrm{NH}_{3}-\mathrm{N}$ values indicated less rate of soluble protein (SP) content, solubilization of true protein occurs in the silo due to the action of plant proteases enzymes. Total VFA's concentration in three kinds of silage appeared to be within the normal range (2.65 to $3.95 \mathrm{~g}$ $\mathrm{kg}$ DM) for good quality silage which indicated acceptable silage fermentation.

Table (3): Silage fermentation characte5ristics ensilage duckweed after 45 days.

\begin{tabular}{|c|c|c|c|c|}
\hline Item & Time (days) & T1 & T2 & T3 \\
\hline \multirow{6}{*}{$\mathrm{pH}$} & 0 & $6.98^{\mathrm{a}} \pm 0.22$ & $6.70^{\mathrm{b}} \pm 0.76$ & $6.55^{\mathrm{c}} \pm 0.02$ \\
\hline & 7 & $5.95^{\mathrm{a}} \pm 0.23$ & $5.70^{\mathrm{b}} \pm 0.24$ & $5.40^{\mathrm{c}} \pm 0.04$ \\
\hline & 21 & $4.45^{\mathrm{a}} \pm 0.34$ & $4.24^{\mathrm{b}} \pm 0.02$ & $4.04^{\mathrm{c}} \pm 0.12$ \\
\hline & 35 & $4.44^{\mathrm{a}} \pm 0.90$ & $4.20^{\mathrm{b}} \pm 0.22$ & $4.02^{c} \pm 0.22$ \\
\hline & 45 & $4.15^{\mathrm{a}} \pm 0.24$ & $4.05^{b} \pm 0.12$ & $3.88^{\mathrm{c}} \pm 0.34$ \\
\hline & 0 & $2.50^{\mathrm{c}} \pm 0.34$ & $2.65^{\mathrm{b}} \pm 0.23$ & $2.70^{\mathrm{a}} \pm 0.04$ \\
\hline \multirow{4}{*}{ NH3-N (g\kg DM) } & 7 & $2.60^{\mathrm{c}} \pm 0.56$ & $2.70^{\mathrm{b}} \pm 0.12$ & $2.75^{\mathrm{a}} \pm 0.45$ \\
\hline & 21 & $2.55^{\mathrm{c}} \pm 0.47$ & $2.80^{\mathrm{b}} \pm 0.21$ & $2.85^{\mathrm{a}} \pm 0.33$ \\
\hline & 35 & $2.75^{\mathrm{c}} \pm 0.06$ & $2.85^{\mathrm{b}} \pm 0.23$ & $2.95^{\mathrm{a}} \pm 0.45$ \\
\hline & 45 & $2.55^{\mathrm{c}} \pm 0.34$ & $2.60^{\mathrm{b}} \pm 0.87$ & $2.75^{\mathrm{a}} \pm 0.20$ \\
\hline \multirow{5}{*}{ TVFA's (g\kg DM) } & 0 & $2.65^{\mathrm{c}} \pm 0.33$ & $2.75^{\mathrm{b}} \pm 0.04$ & $2.85^{\mathrm{a}} \pm 0.05$ \\
\hline & 7 & $3.00^{\mathrm{c}} \pm 0.52$ & $3.10^{\mathrm{b}} \pm 0.91$ & $3.19^{\mathrm{a}} \pm 0.32$ \\
\hline & 21 & $3.40^{\mathrm{c}} \pm 0.22$ & $3.50^{\mathrm{b}} \pm 0.12$ & $3.60^{\mathrm{a}} \pm 0.23$ \\
\hline & 35 & $3.60^{\mathrm{c}} \pm 0.34$ & $3.75^{\mathrm{b}} \pm 0.45$ & $3.86^{\mathrm{a}} \pm 0.11$ \\
\hline & 45 & $3.63^{\mathrm{c}} \pm 0.35$ & $3.75^{\mathrm{b}} \pm 0.23$ & $3.95^{\mathrm{a}} \pm 0.14$ \\
\hline
\end{tabular}

a,b and ${ }^{\mathrm{c}}$ Means in the same row with different superscript are significantly $(\mathrm{P}<0.05)$.

T1: $55 \%$ duckweed $+40 \%$ rice straw $+5 \%$ molasses.

T2: $60 \%$ duckweed $+35 \%$ rice straw $+5 \%$ molasses.

T3: $65 \%$ duckweed $+30 \%$ rice straw $+5 \%$ molasses . 
Journal of Environmental Sciences (JES)

Faculty of Graduate Studies and Environmental Research, Ain Shams University

Abdel-Rahman., et al.

Digestibility coefficients and nutritive values: Data of Table (4) clearly indicated that animals fed R3 recorded the highest digestibility values of $\mathrm{DM}, \mathrm{OM}, \mathrm{CP}, \mathrm{CF}, \mathrm{EE}, \mathrm{NFE}$ and nutritive values as (TDN and DCP) compared with other rations. Results indicated that replacement corn silage by duckweed waste silage at $100 \%$ in ration $\mathrm{R}_{3}$ had significant $(\mathrm{P}<0.05)$ effect on all nutrient digestibility coefficients compared with control ration (R1). These results are in agreement with those obtained by (Goopy, 2003) and Indulekha et al., (2019) reported that DM and OM digestibility tended to remain affected, $\mathrm{CP}$ digestibility was increased and crude fiber fractions (NDF and ADF) digestibility were increased when duckweed in rations substitute for starchy feeds. The high values of TDN and DCP of ration R3 contained $1.75 \%$ of body weights CFM + duckweed silage may be attributed to the mutual associative effect of highest nutrients digestibility. These results are in accordance with those obtained by (Goopy, 2003) and Landolt (1986). The difference in digestibility coefficients and nutritive values may be due to difference in extent of washing during harvest of azolla (Puneet, et al., 2020). 
Table (4): Nutrients digestibility and nutritive values of experimental rations by Barki lambs.

\begin{tabular}{|c|c|c|c|c|}
\hline \multirow{2}{*}{ Item } & \multicolumn{5}{|c|}{ Experimental rations } \\
\cline { 2 - 5 } & R1 & R2 & R3 & R4 \\
\hline \hline DM & $76.54 \mathrm{c} \pm 0.28$ & $76.94 \mathrm{c} \pm 0.87$ & $81.92 \mathrm{a} \pm 0.46$ & $80.91 \mathrm{~b} \pm 0.32$ \\
\hline OM & $69.26 \mathrm{~b} \pm 0.31$ & $68.72 \mathrm{~b} \pm 0.99$ & $72.50 \mathrm{a} \pm 0.58$ & $70.37 \mathrm{~b} \pm 0.48$ \\
\hline CP & $69.03 \mathrm{c} \pm 0.77$ & $69.96 \mathrm{c} \pm 0.17$ & $78.77 \mathrm{a} \pm 0.44$ & $74.93 \mathrm{~b} \pm 0.53$. \\
\hline CF & $52.13 \mathrm{c} \pm 0.94$ & $55.10 \mathrm{c} \pm 0.37$ & $66.12 \mathrm{a} \pm 0.44$ & $58.85 \mathrm{~b} \pm 0.11$ \\
\hline EE & $83.91 \mathrm{~b} \pm 0.52$ & $84.99 \mathrm{ab} \pm 0.32$ & $89.86 \mathrm{a} \pm 0.63$ & $87.25 \mathrm{ab} \pm 0.11$ \\
\hline NFE & $73.68 \pm 0.65$ & $71.77 \pm 0.17$ & $72.14 \pm 0.49$ & $71.75 \pm 0.57$ \\
\hline Cell wall constituents \%: \\
\hline NDF & $60.98 \mathrm{c} \pm 0.22$ & $60.40 \mathrm{c} \pm 0.55$ & $63.70 \mathrm{a} \pm 0.46$ & $61.40 \mathrm{~b} \pm 0.43$ \\
\hline ADF & $52.33 \mathrm{c} \pm 0.43$ & $52.43 \mathrm{c} \pm 0.63$ & $54.60 \mathrm{a} \pm 0.13$ & $53.43 \mathrm{~b} \pm 0.14$ \\
\hline ADL & $40.62 \mathrm{c} \pm 0.56$ & $40.82 \mathrm{c} \pm 0.17$ & $44.75 \mathrm{a} \pm 0.66$ & $41.82 \mathrm{~b} \pm 0.34$ \\
\hline Cellulose & $20.48 \mathrm{c} \pm 0.04$ & $20.55 \mathrm{c} \pm 0.33$ & $22.62 \mathrm{a} \pm 0.23$ & $21.55 \mathrm{~b} \pm 0.99$ \\
\hline Hemicelluloses & $50.93 \mathrm{c} \pm 0.54$ & $50.89 \mathrm{c} \pm 0.54$ & $55.72 \mathrm{a} \pm 0.12$ & $52.89 \mathrm{~b} \pm 0.45$ \\
\hline \multicolumn{5}{|c}{ Feeding value \%: } \\
\hline TDN & $65.08 \mathrm{~b} \pm 0.32$ & $64.40 \mathrm{~b} \pm 0.94$ & $67.81 \mathrm{a} \pm 0.50$ & $66.27 \mathrm{ab} \pm 0.44$ \\
\hline DCP & $9.35 \mathrm{~b} \pm 0.11$ & $9.50 \mathrm{~b} \pm 0.17$ & $10.38 \mathrm{a} \pm 0.59$ & $10.30 \mathrm{a} \pm 0.72$ \\
\hline a,b and c ${ }^{\mathrm{c}}$ Means in the same row with different superscript are significantly
\end{tabular}

$(\mathrm{P}<0.05)$.

$\mathrm{R} 1: 2 \%$ of body weights $(\mathrm{CFM})+\mathrm{CS}$ (control).

R2: $1.5 \%$ of body weights CFM + DS.

R3: $1.75 \%$ of body weights CFM + DS.

R4: $2 \%$ of body weights CFM + DS.

Rumen parameters: Rumen liquor parameters of lambs fed tested rations are showed in Table (5). The $\mathrm{pH}$ means of rumen liquor at zero time were nearly similar and not significant in among different groups with highest 
Journal of Environmental Sciences (JES)

Faculty of Graduate Studies and Environmental Research, Ain Shams University

Abdel-Rahman., et al.

value (6.78) in $\mathrm{R} 1$. While, at 3 and 6 hours after feeding $\mathrm{pH}$ values increased with R2, R3 and R4 feeding duckweed in tested rations with significant differences $(\mathrm{P}<0.05)$ between $\mathrm{R} 4$ which had the highest average (6.45) as compared to R1 (control group) which had the lowest average (6.01). The ruminal $\mathrm{pH}$ value is a result of changes in the quantities of metabolites especially VFA and ammonia, produced in the digest. It varies depending on many factors such as the physical and chemical characteristics of the diet and the sampling time of the rumen liquor. These results confirmed those stated by Kaufmann (1972) that the regulation mechanism of the ruminants is adjusted and not directed towards maintaining medium or normal $\mathrm{pH}$ value. The ruminal $\mathrm{pH}$ value is a result of changes in the quantities of metabolites especially VFA and ammonia, produced in the digest. It varies depending on many factors such as the physical and chemical characteristics of the diet and the sampling time of the rumen liquor. (El-Shzly et al., 1963; Hungate, 1967 and Indulekha et al., (2019).

The concentration of ammonia-nitrogen in rumen liquor of lambs fed R3 recorded higher level at zero time, 3 and 6 hrs. after feeding compared with other groups with significant differences $(\mathrm{P}<0.05)$ as compared with control group (R1) at zero time and 3 hrs. Hanafy (1985) and Tabana (1994) found that NH3-N concentration in the rumen was markedly higher at 3 and 6 hrs. after feeding. The concentration of total volatile fatty acids (TVFA's) in rumen liquor, significantly differences $(\mathrm{P}<0.05)$ by testing rations. $\mathrm{R} 3 \mathrm{had}$ 650 
the highest values of (TVFA's) at zero time, 3 and 6 hours after feeding. While, control group (R1) had the lowest average of TVFA's at zero, 3 and 6 hours after feeding. These results agree with Tabana (1994). Lewis et al. (1996) observed that fibrocystic enzyme treatment significantly decreased ruminal $\mathrm{pH}$ increased TVFA's concentration in the rumen.

Table (5): Rumen liquor parameters for animals fed the experimental rations.

\begin{tabular}{|c|c|c|c|c|c|}
\hline \multirow{2}{*}{ Item } & Time & \multicolumn{4}{|c|}{ Experimental rations } \\
\cline { 3 - 6 } & $($ hrs.) & $\mathbf{R 1}$ & $\mathbf{R 2}$ & $\mathbf{R 3}$ & $\mathbf{R 4}$ \\
\hline \multirow{3}{*}{$\mathrm{pH}$} & 0 & $6.78 \pm 0.03$ & $6.75 \pm 0.04$ & $6.71 \pm 0.02$ & $6.73 \pm 0.03$ \\
\cline { 2 - 6 } & 3 & $6.01 \mathrm{~b} \pm 0.04$ & $6.21 \mathrm{a} \pm 0.05$ & $6.24 \mathrm{a} \pm 0.02$ & $6.19 \mathrm{a} \pm 0.03$ \\
\cline { 2 - 6 } & 6 & $6.20 \mathrm{~b} \pm 0.04$ & $6.41 \mathrm{a} \pm 0.03$ & $6.38 \mathrm{a} \pm 0.02$ & $6.45 \mathrm{a} \pm 0.02$ \\
\hline \multirow{2}{*}{$\begin{array}{c}\mathrm{NH} 3-\mathrm{N} \\
(\mathrm{mg} / 100 \mathrm{ml})\end{array}$} & 0 & $9.58 \mathrm{~d} \pm 0.41$ & $11.00 \mathrm{c} \pm 0.25$ & $13.50 \mathrm{a} \pm 0.43$ & $12.15 \mathrm{~b} \pm 0.13$ \\
\cline { 2 - 6 } & 3 & $22.33 \mathrm{~d} \pm 0.56$ & $25.00 \mathrm{c} \pm 0.32$ & $32.73 \mathrm{a} \pm 0.85$ & $28.53 \mathrm{~b} \pm 0.34$ \\
\cline { 2 - 6 } & 6 & $11.90 \mathrm{c} \pm 0.04$ & $13.68 \mathrm{~b} \pm 0.52$ & $17.55 \mathrm{a} \pm 0.47$ & $14.38 \mathrm{~b} \pm 0.37$ \\
\hline \multirow{2}{*}{$\begin{array}{c}\text { TVFA's } \\
\text { (meq./100ml) }\end{array}$} & 0 & $4.80 \mathrm{c} \pm 0.14$ & $5.55 \mathrm{~b} \pm 0.25$ & $6.86 \mathrm{a} \pm 0.13$ & $6.05 \mathrm{~b} \pm 0.06$ \\
\cline { 2 - 6 } & 3 & $7.58 \mathrm{c} \pm 0.38$ & $9.32 \mathrm{~b} \pm 0.27$ & $12.00 \mathrm{a} \pm 0.27$ & $10.03 \mathrm{~b} \pm 0.16$ \\
\cline { 2 - 6 } & 6 & $6.03 \mathrm{c} \pm 0.34$ & $7.23 \mathrm{~b} \pm 0.13$ & $8.55 \mathrm{a} \pm 0.15$ & $7.65 \mathrm{~b} \pm 0.18$ \\
\hline
\end{tabular}

$\mathrm{a}, \mathrm{b}$, and ${ }^{\mathrm{c}}$ Means within the same row with different superscripts differ $(\mathrm{P}<0.05)$.

R1: $2 \%$ of body weights (CFM) + CS (control).

R2: $1.5 \%$ of body weights CFM + DS.

R3: $1.75 \%$ of body weights CFM + DS.

R4: $2 \%$ of body weights CFM + DS.

Blood serum parameters: Blood serum constituents of Barki lambs fed the experimental rations are presented in Table (6). No significant differences $(\mathrm{P}<0.05)$ between all rations for urea- $\mathrm{N}$ concentration in the serum of feeding lamb CS or DS ration $(25.20,24.85,24.79$ and $24.50 \mathrm{mg} / \mathrm{dl})$ for R1, 
R2, R3 and R4, respectively. The normal levels of serum urea-N in sheep and goats range from 8 to $40 \mathrm{mg} / \mathrm{dl}$ (Rakha, 1988). No significant differences $(\mathrm{P}<0.05)$ between all rations for total protein $(\mathrm{TP})$ in the serum of lamb fed on CS or DS for ration (7.40, 7.40, 7.35 and $7.32 \mathrm{~g} / \mathrm{dl}$ ) for R2, $\mathrm{R} 4, \mathrm{R} 3$ and R1, respectively. The present estimates within the normal range of total protein $(6-8 \mathrm{~g} / \mathrm{dl})$ reported by Recce (1991) and close to the value (6-9 g/dl) reported by Smith et al. (1979). No significant differences $(\mathrm{P}<0.05)$ between all rations for albumin in the serum of lamb fed on CS or DS ration (3.90, 3.84, 3.80 and $3.78 \mathrm{~g} / \mathrm{dl})$ for $\mathrm{R} 1, \mathrm{R} 2, \mathrm{R} 4$ and $\mathrm{R} 3$, respectively. No significant differences $(\mathrm{P}<0.05)$ between all treatments for ALT and AST in the serum of lamb fed on CS or DS ration (20.52, 20.46, 20.44 and $20.40 \mathrm{U} / \mathrm{L})$ and $(33.71,33.67,33.59$ and $33.50 \mathrm{U} / \mathrm{L})$ for R2, R1, R4 and R3, respectively. In general, the values recorded for AST and ALT were within the normal range reported by Abd El-Kareem (1990) and Mahrous et al. (2019) found that values ranged from 24 to 65 and from 14 to $37 \mathrm{U} / \mathrm{L}$ for AST and ALT, respectively. 
Table (6): Effect of experimental ration on blood serum parameters for lambs.

\begin{tabular}{|c|c|c|c|c|}
\hline \multirow{2}{*}{ Item } & \multicolumn{3}{|c|}{ Experimental rations } & \\
\cline { 2 - 5 } & $\mathbf{R 1}$ & $\mathbf{R 2}$ & $\mathbf{R 3}$ & $\mathbf{R 4}$ \\
\hline \hline $\begin{array}{c}\text { Urea nitrogen, } \\
\text { (mg/100ml) }\end{array}$ & $25.20 \pm 0.23$ & $24.85 \pm 0.12$ & $24.79 \pm 0.14$ & $24.50 \pm 0.52$ \\
\hline $\begin{array}{c}\text { Total protein } \\
\text { (gm/100ml) }\end{array}$ & $7.32 \pm 0.22$ & $7.40 \pm 0.40$ & $7.35 \pm 0.23$ & $7.40 \pm 0.67$ \\
\hline Albumin (gm/100ml) & $3.90 \pm 0.42$ & $3.84 \pm 0.23$ & $3.78 \pm 0.52$ & $3.80 \pm 0.04$ \\
\hline Globulin (gm/100ml) & $3.42 \pm 0.35$ & $3.56 \pm 0.15$ & $3.57 \pm 0.12$ & $3.60 \pm 0.11$ \\
\hline AST (U/L) & $20.46 \pm 0.22$ & $20.52 \pm 0.52$ & $20.40 \pm 0.26$ & $20.44 \pm 0.52$ \\
\hline ALT (U/L) & $33.67 \pm 0.25$ & $33.71 \pm 0.23$ & $33.50 \pm 0.75$ & $33.59 \pm 0.82$ \\
\hline
\end{tabular}

R1: $2 \%$ of body weights (CFM) + CS (control).

R2: $1.5 \%$ of body weights CFM + DS.

R3: $1.75 \%$ of body weights CFM + DS.

R4: $2 \%$ of body weights CFM + DS.

Growth performance and economic efficiency: The average values of feed intake, daily gain, feed conversion and economic efficiency are shown in Table (7). Data revealed that total body gain and daily gain were increased for lambs fed rations containing duckweed silage (R3 and R4). These results may be related the increasing digestibility coefficients and rumen activity for R3 and R4. The highest value of DMI was observed in R1 (1138g/h/d) followed by R2 (1047g/h/d), respectively. Sireesha et al., (2017) and Dongare et al. (2019) concluded that feeding of $10 \%$ replacement level of azolla in the basal diet significantly improved the average body weight gain of rabbits Growth Performance of Newzealand 
Journal of Environmental Sciences (JES)

Faculty of Graduate Studies and Environmental Research, Ain Shams University

Abdel-Rahman., et al.

White Rabbits Fed.. 632 when compared to that of T1 and T3. Various studies revealed that, feeding of Azolla in dairy animals, increases milk production by $15-20$ per cent when $1.5 \mathrm{~kg}-2 \mathrm{~kg}$ of Azolla was combined with the concentrate feed (Pankaj et al., 2019) and Ninad et al., (2020). Ninad et al. (2020) researched on goat kids with the following feeding patterns that is $\mathrm{T} 1$ (Grazing $+100 \%$ concentrate), T2 (Grazing+ 80\% concentrate $+20 \%$ Azolla) and T3 (Grazing $+70 \%$ concentrate $+30 \%$ Azolla) and found that the average daily weight gain (ADG) of goat kids was $0.10,0.23$ and $0.25 \mathrm{~kg}$ respectively in $\mathrm{T} 1, \mathrm{~T} 2$ and $\mathrm{T} 3$ groups.

The best feed conversion (Table 7) was that for lambs fed R3. The energy intake (TDNI) was higher for control ration $(741 \mathrm{~g} / \mathrm{h} / \mathrm{d})$ compared with other ratios. This could be mainly due to the more DMI. Feed conversion expressed as $(\mathrm{g} D \mathrm{DM} / \mathrm{g}$ gain) was better $(\mathrm{P}<0.05)$ with ration (3.75, 5.34 for R3 and R4 compared with R2 and R1 as a control (5.61 and 5.84). The improvement of feed conversion may be due to improvement in both nutrient digestibility and nutritive value. Economics of feeding duckweed silage to growing lambs is presented in Table (7). Average daily feed cost (L.E.) decreased with highest value in R4 (3.40 L.E.) and the lowest value (2.35 L.E.) in R2. 
Journal of Environmental Sciences (JES)

Faculty of Graduate Studies and Environmental Research, Ain Shams University

Abdel-Rahman., et al.

Table (7): Effect of experimental rations on growth performance of lambs during (120 days).

\begin{tabular}{|c|c|c|c|c|}
\hline \multirow{2}{*}{ Item } & \multicolumn{4}{|c|}{ Experimental rations } \\
\hline & $\mathbf{R 1}$ & R2 & $\mathbf{R 3}$ & $\mathbf{R 4}$ \\
\hline No of animal & 5 & 5 & 5 & 5 \\
\hline Initial weight $\mathrm{Kg}$ & $20.40 \pm 0.24$ & $21.00 \pm 0.44$ & $21.00 \pm 0.44$ & $21.00 \pm 0.44$ \\
\hline Final weight, $\mathrm{Kg}$ & $43.80 \mathrm{c} \pm 0.33$ & $43.40 \mathrm{c} \pm 0.16$ & $47.40 \mathrm{a} \pm 0.04$ & $45.80 \mathrm{~b} \pm 0.33$ \\
\hline Total gain, $\mathrm{Kg}$ & $23.40 \mathrm{c} \pm 0.24$ & $22.40 \mathrm{~d} \pm 0.32$ & $26.40 \mathrm{a} \pm 0.40$ & $24.40 \mathrm{~b} \pm 0.32$ \\
\hline Daily gain, $\mathrm{g}$ & $195.00 \mathrm{c} \pm 0.02$ & $186.60 \mathrm{~d} \pm 0.06$ & $220.20 \mathrm{a} \pm 0.35$ & $206.40 \mathrm{~b} \pm 0.18$ \\
\hline \multicolumn{5}{|c|}{ DM intake, $(\mathrm{g} / \mathrm{h} / \mathrm{d})$} \\
\hline CFM & 883.50 & 746.25 & 604.75 & 815 \\
\hline $\mathrm{CS}$ & 0.00 & 0.00 & 0.00 & 287.50 \\
\hline DS & 254.5 & 301.5 & 222 & 0.00 \\
\hline Total DM intake $(\mathrm{g} / \mathrm{h} / \mathrm{d})$ & 1138 & 1047.75 & 826.75 & 1102.50 \\
\hline TDN intake $(\mathrm{g} / \mathrm{h} / \mathrm{d})$ & 741 & 675 & 561 & 731 \\
\hline DCP intake (g/h/d) & 106.40 & 99.54 & 85.81 & 113.56 \\
\hline \multicolumn{5}{|c|}{ Feed conversion (g DM/g gain): } \\
\hline DM & 5.84 & 5.61 & 3.75 & 5.34 \\
\hline TDN & 3.80 & 3.72 & 2.55 & 3.54 \\
\hline DCP & 0.55 & 0.53 & 0.39 & 0.55 \\
\hline Av. feed Cost (h/d/LE) & 3.26 & 2.35 & 2.91 & 3.40 \\
\hline Av. Revenue if daily gain (LE) & 12.68 & 12.12 & 14.30 & 13.43 \\
\hline Net Revenue (LE/ h/d ) & 9.42 & 9.77 & 11.39 & 10.03 \\
\hline *Economic efficiency (\%) & 3.89 & 5.16 & 4.91 & 3.95 \\
\hline
\end{tabular}

${ }^{\mathrm{a}}$ and ${ }^{\mathrm{b}}$ Means within the same row with different superscripts differ $(\mathrm{P}<0.05)$.

R1: $2 \%$ of body weights $(\mathrm{CFM})+\mathrm{CS}$ (control). $\quad \mathrm{R} 2: 1.5 \%$ of body weights CFM + DS.

R3: $1.75 \%$ of body weights CFM + DS. R4: $2 \%$ of body weights CFM + DS. The price of feedstuffs and products:

$\mathrm{CFM}=3700 \mathrm{~L} . \mathrm{E} /$ ton, $\mathrm{CS}=850 \mathrm{~L} . \mathrm{E} / \mathrm{ton}, \mathrm{DS}=500 \mathrm{~L} . \mathrm{E} /$ ton and $1 \mathrm{~kg} \mathrm{LBW}=65 \mathrm{~L} . \mathrm{E}$

$*$ Economic efficiency*= price $/ \mathrm{kg} \mathrm{LBW} /$ Feed cost (L.E/kg gain).

Vol.(50); Iss.(10); No.(7); Oct.. 2021

ISSN $1110-0826$

Online ISSN 2636-3178 


\section{CONCLUSION}

It could be concluded that incorporation of replacement corn silage by duckweed silage lamb rations improve digestibility, nutritive value and performance of growing lambs meanwhile and decreased the cost of feeding lamb because replacement corn silage by duckweed silage and (R3) showed the best results.

\section{REFERENCES}

A.O.A.C (2000): Official Methods of Analysis 17th Ed., Associations of Official Analytical Chemists, Washington, D.C., U.SA.

Abd El Kareem, F.A. (1990): Improvement the utilization of roughage by goats. Ph..D Thesis, Fac. of Agric, Cairo Univ. Egypt. pp. 7073.

Abou-Akkada, A. R. and H. E. Osman (1967): Studies on the utilization of non-protein nitrogen in Egypt. J. Agric. Sci., 169: 25-33.

Alica, B.; S. Maros and F. Jozef (2015): Comprehensive study of duckweed cultivation and growth conditions under controlled eutrophication. Trnava J. 23 (6): 103-107.

Armstrong, W. D. and C. W. Carr (1964): Physiological. Chemistry 3rd ed. pp., 75 Burges Publishing CO. Minneapolis, Minnesota, USA.

Badawy, H. S. (2014): Utilization of Canola meal as a source of protein for fattening lambs. Egyptian J. Nutrition and Feeds, 17(2):257-273.

Bergen, W. G.; E. H. Cach and H. E. Henderson (1974): Changes in nitrogenous compounds of the whole corn plant during ensiling and subsequent effects on dry matter intake by sheep. J. Animals . Sci., 39:629.

656 
Dongare, S.V., A.A. Hanmante, H.R. Agare, D.J. Bhagat and I.G. Gawas (2019): Effect of feeding fresh azolla (Azolla pinnata) on milk production of Konkan kanyal goat. International Journal of Chemical Studies 2019; 7(5): 1298-1301.

Doumas, B. T.; W. A. Wastson and H. G. Biggs (1971): Albumin standards and the measurement of serum albumin with bromocresol green. Clin. Chem. Acta., 31:87-90.

Duncan, D. B. (1955): Multiple range and multiple F -test. Biometrics, 11:1.

El-Shazly, K.; E. A. Ibrahim and H. A. Kara, (1963): Nutritional value of date seeds for sheep. J. Anim. Sci., 22 (4): 894-897.

Goopy, J. M. P. (2003): A review on the role of duckweed in nutrient reclamation and as a source of animal feed. Asian-Australas. J. Anim Sci 16(2):297-305.

Hanafy, M. A. (1985): Nutritional evaluation of ensiled by-products with or without forages. PH.D. thesis, Fac. Of Agric., Cairo Univ.

Hungate, R. E. (1967).: Hydrogen as an intermediate in the rumen fermentation Archiv für Mikrobiologie. 59, 158-164.

Indulekha, V.P., C. George and K.S. Anil. (2019): Utilization of water hyacinth as livestock feed by ensiling with additives. Indian Journal of Weed Science 51(1): 67-71, 2019.

Kaufmann, W. (1972): Uber die regulierung des $\mathrm{pH}$ wertesim haubenpansen der wiederkauer. Tiervarztl. Umscbau. 27:324. (cited from El-Ashmawey,M.M.I. (2003 ).

Landolt, E. (1986): The Family of Lemnacae - A Monographic Study vol 1. Part of the series: Biosystematic Investigations in the family of duckweeds (Lemnacae), Vol 2 of 4. Veroffentlichungen Des Geobotanischen (pub.) 
Leng, R. A. (1999): Duckweed, A Tiny Aquatic Plant with Enormous Potential for Agriculture and Environment FAO. Tran Phu Printing Co.

Lewis, G. E., C. W. Hunt, W. K. Sanchez, R. Treacher, G. T. Pritch-ard, and P. Feng. (1996): Effect of direct-fed fibrolytic enzymes on the digestive characteristics of a forage-based diet fed to beef steers. J. Anim. Sci. 74:3020-3028.

Mahrous A.A.; A. S. Karkoutli; A. A. H. El-Tahan; Y. H. Hafez; A. A. Abu El-Allaand S. K. Moussa. (2019): Replacement corn silage by orange waste silage in barki ram lambs rations. Egyptian J. Nutrition and Feeds (2019), 22(2) Special Issue: 111-119.

Ninad Bhatt, Nripendra Pratap Singh, Amit Kumar Singh, Diksha Kandpal, Pramod Chaudhary and Priyanka Patoliya: Azolla - A potent unconventional feed and its effect of feeding on various livestock species -A Review. Journal of Entomology and Zoology Studies. 8(2): 1693-1698, (2020).

Ninad Bhatt, Suresh Kumar, Koushal Singh, Ramesh Chandra, Amit Kumar Singh, Asish Debbarma, Rajneesh, Mahesh Bipate and Amol Adbhai: Behavioural investigation of Sahiwal calves under Azolla pinnata feeding in early morning hours during cold season. Journal of Entomology and Zoology Studies. 8(2): 310313 , (2020).

NRC. (1985): Nutrient Requirements of Domestic Animals Nutrient Requirements of Sheep 5th Ed. National Academy of sciencesNational Research council, Washington D. C. , USA.

Pankaj Lavania, Suresh Chandra Jingar, Heeral Lal Bugalia, Shiv Murat Meena and Ajesh Kumar: Effect of Azolla feeding as a supplement on milk and reproduction performance on zebu cattle under field condition. International Journal of Chemical Studies. 7(3): 3167-3168, (2019). 
Puneet Sharma , A. Chatterjee, Yogeshwar Prasad, M. K. Ghosh and Bhawana Shukla: Chemical composition and comparative protein fraction of Azolla microphylla with conventional fodders. Veterinary Research International Journal homepage: www.jakraya.com/journal/vri, (2020).

Rakha G.M. (1988): Studies on the effect of using-agro industrial byproducts on health and production of some farm animals. Ph.D. Thesis. Fac. of Vet. Med.Cairo Univ., Egypt.

Recce, W. O. (1991): Physiology of domestic animals lea and Febiger, Philadlhpi, USA.

Reitman, S. and S. Frankel (1957): Colorimetric determination of GPT activity according to the Reitman and Frankel method. Am. J.clim.path.28.

Renu Kumari, R.K. Dhuria, N.V. Patil, R.K. Sawal and Sanjay Singh: Chemical composition and pellet quality of Azolla pinnata grown in semi-arid zone of India. International Journal of Chemical Studies. 6(3): 2031-2033, (2018).

S.A.S. (2001): SAS user's guide: Statistics, 6th Ed. Cary, N.C.: SAS Institute, Inc. Cary. NC. USA.

Siest, G.; J. Henny and F. Schiela (1981): Interpretion des examens de laboratories, PP. 206, Karger Ed.

Sireesha, K., M. Kalyana Chakravarthi, G. Gangaraju and J.V. Ramana, J. Suresh and B.R. Naik: Growth performance of newzealand white rabbits fed with graded levels of azolla (azolla pinnata) in the basal diet. International Journal of Science, Environment and Technology, Vol. 6, No 1, 2017, 630 - 634. (2017).

Smith, I. W.; C. C. Calvert and H. R. Cross. (1979): Dehydrated poultry excrate vs. cottonseed meal as a nitrogen supplements for Holstein steers. J. Anim. Sci., 48: 633. 
Sonam Mishra, V.N. Khune, Swarnalata Bara and Sweta Banjara (2020): Nutritional evaluation of Azolla pinnata. The Pharma Innovation Journal. 9(6): 16-17.

Tabana, A.S.A. (1994): Utilization of corn and sunflower plant residues in ruminants nutrition. M.Sc. Thesis, Fac. Agric., Cairo, University. Egypt.

Thomas, C.G. (2008): Forage Crop Production in the Tropics (2nd Ed.). Kalyani Publishers, New Delhi, 333p.

Warner, A. C. I. (1964): Production of volatile fatty acids in the rumen, methods of measurements. Nutr. abstr. and Rev., 34: 339.

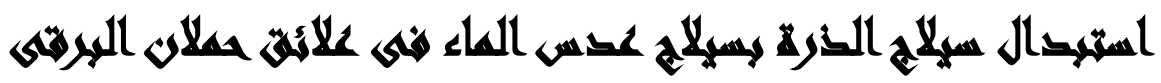

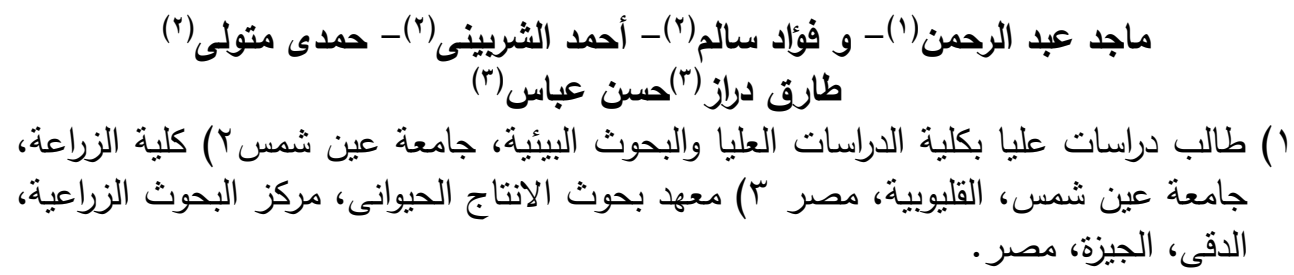

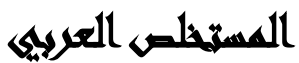

أجريت هذه الدراسة لتقييم تاثير إحلال سيلاج عدس الماء محل سيلاج الذرة على الاداء

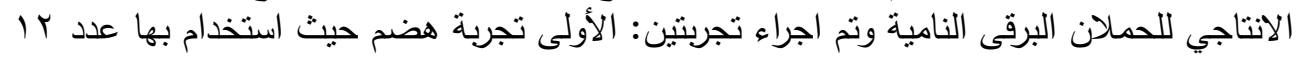
من كباش برقى بعد انتهاء تجربة النمو وتم اجراء التحليلات التئية الكيميائية للعلائق المختبرة ومعاملات بهات الهضم والقيمة الغذائية.

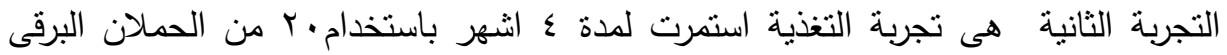

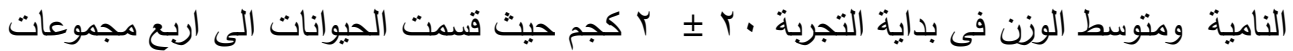
(كل مجموعة خمسة حيوانات) وغذيت على العلائق التجريبية. وتم تقدير أداء الاغنام كل اسبوعين 
من خلال تقدير معدل الزيادة اليومية والمأكول من المادة الجافة والكفاءة الغذائية. غذيت الاغنام على النحو التالى : عنى

المجموعة الأولى: ب \% من وزن الجسم مخلوط علف مركز + سيلاج ذرة (مجموعة المقارنة).

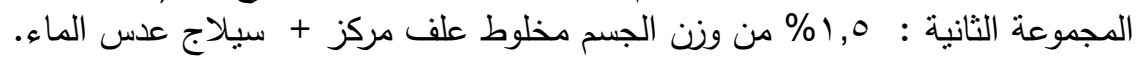

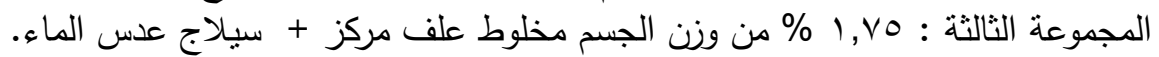

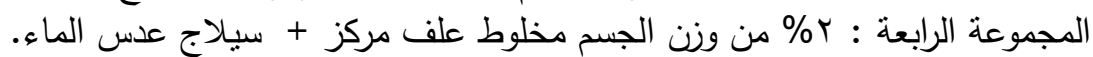

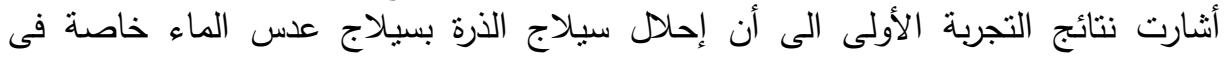

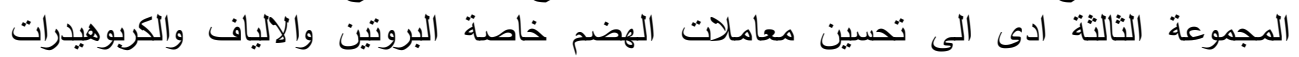

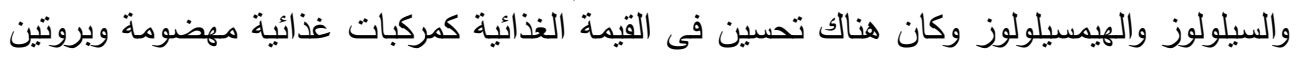

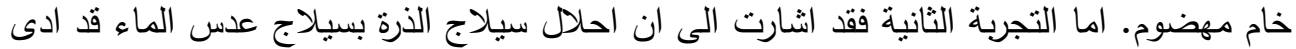

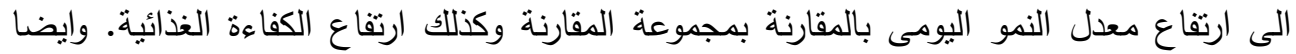

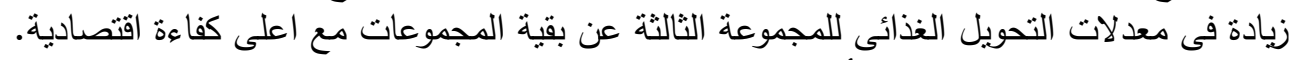

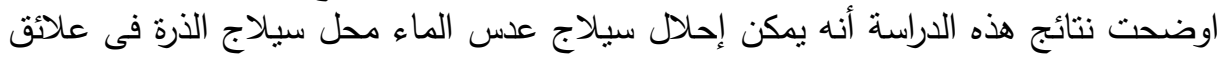

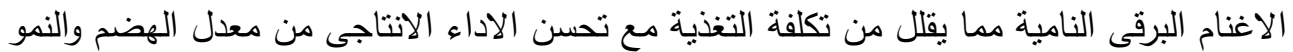

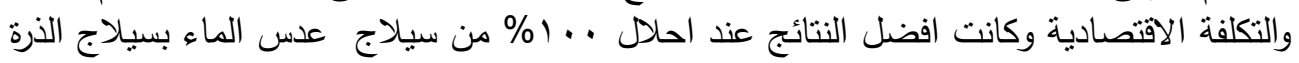

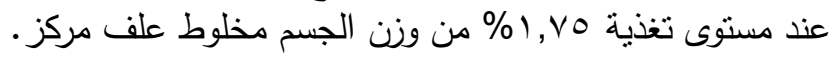

